\title{
Miguel González Ancín y Otis Towns, Miguel Servet en España (1506-1527). Edición ampliada, La Vergne, TN, IngramSpark, 2018, 469 pp. ISBN: 978-84-697-8054-1
}

\section{Fabrice Quero}

Université Paul-Valéry Montpellier 3

FRANCIA

fabrice.quero@univ-montp3.fr

[Hipogrifo, (issn: 2328-1308), 9.1, 2021, pp. 1377-1379]

Recibido: 16-11-2020 / Aceptado: 06-12-2020

DOI: http://dx.doi.org/10.13035/H.2021.09.01.77

En la biografía y en la obra de Miguel Servet están en juego las principales problemáticas de los albores de la época moderna en Europa y, de manera especial, la revolución intelectual -lato sensu- y religiosa, que se produce en aquel momento. Es más, aparece en toda la complicación de la articulación entre esas dos dimensiones. El destino trágico de uno de los espíritus más fértiles de su época potenció, de manera temprana, la floración de una bibliografía amplia y variopinta en torno a una vida con varias zonas oscuras y una personalidad de ingente complejidad. El Instituto de Estudios Sijenenses "Miguel Servet"/Michael Servetus Institute asume un papel activo en la publicidad en torno a las actividades y producciones escritas que tienen a Miguel Servet como objeto, de manera actualizada, dentro de un proyecto general de promoción, en un principio de siglo XXI convulso, de la actualidad de una figura y de los debates, antaño entre humanistas, en torno a la idea de tolerancia. La diversidad de la oferta en el portal de dicho instituto testimonia la fascinación que sigue ejerciendo Miguel Servet, especialmente en Aragón.

Prueba de ello es también la publicación en 2018, por Miguel González Ancín y Otis Towns, de una versión ampliada de un estudio titulado Miguel Servet en España (1506-1527) - publicado por primera vez el año anterior- que abarca el perfil humano de Servet y asume el humanitarismo del que el médico aragonés es parangón según J. Barón Fernández. Los dos autores revelan con gran sinceridad la vinculación de la investigación, cuyo fruto se presenta en el estudio, con la tradición 
y los orígenes familiares del primero de ellos. A nivel científico, el libro se sitúa en la continuidad de las investigaciones de Francisco Javier González Echevarría -con quien Miguel González Ancín comparte la autoría de un artículo-, y especialmente con El amor a la Verdad. Vida y obra de Miguel Servet (2011).

Dentro de una biografía enmarañada, los autores enfocan la infancia y la juventud de Miguel Servet, desde su nacimiento hasta los primeros años de docencia junto a Gaspar Lax en el estudio general de Zaragoza. La ambición es triple. En torno a investigaciones sobre la familia de Miguel Servet, su apellido y su formación, se trata básicamente de demostrar el origen judeoconverso del personaje. Pero este proyecto abarca también incursiones en la historia del humanismo y del erasmismo en Zaragoza. El estudio propiamente dicho (242 páginas) queda completado por un amplio apéndice documental y la reproducción de algunos diplomas (200 páginas). Aunque las referencias bibliográficas completas aparecen en notas, el lector interesado en el tema puede lamentar la ausencia de una bibliografía general así como de un índice que habría facilitado navegar en los entresijos de una minuciosa encuesta por la documentación disponible en varios archivos entre los cuales destacan los fondos del Archivo Histórico de Protocolos Notariales de Zaragoza.

El plan seguido combina secciones biográficas consagradas a Servet, a miembros de su familia o a personajes importantes en su biografía, y apartados monográficos consagrados a cuestiones contextuales, especialmente sobre la patria del personaje, Villanueva de Sigena, o en cuanto a instituciones escolares o universitarias en las que se formó o enseñó Miguel Servet. Los presupuestos epistemológicos son de una gran sencillez y honestidad intelectual a la vez. En el caso de una biografía con muchísimas lagunas, confusiones y hasta mistificaciones, especialmente en las declaraciones de Servet durante sus dos procesos inquisitoriales, es primordial distinguir lo que se sabe de lo que se ignora y extrapola, aunque solo conduzca a retocar unas hipótesis. El meticuloso rastreo de las informaciones por la documentación manuscrita manejada, desconocida hasta ahora en gran parte, responde a la elección de una metodología de inspiración positivista que conduce a explotar la totalidad de las informaciones presentes en ella. El rigor extremo con que se leen, estudian y transcriben los manuscritos desemboca algunas veces en un discurso ligeramente atomizado o centrífugo que requiere una lectura atenta. El largo capítulo consagrado a la universidad de Zaragoza, verdadero ensayo interpolado en el libro, adolece de este planteamiento general. Pero semejante procedimiento es garantía también de la solidez de los datos aportados y del alcance de la discusión de los presupuestos más admitidos entre los especialistas de la biografía de Miguel Servet. Permite incluso corregir unos errores arrastrados en la bibliografía más autorizada.

La encuesta llevada a cabo por Miguel González Ancín y Otis Towns empieza por el final del recorrido vital de Miguel Servet al atender la mención, en el proceso ginebrense de 1553, del defecto congénito que aquejaba al famoso aragonés. A partir de ello, se procede a la reconstitución de la historia familiar dentro de los dominios de la Orden de San Juan, entre Cascante - posible lugar de nacimiento de Servet - y Villanueva de Sigena donde residía buena parte de la familia. La recons- 
titución de los posibles vínculos entre Nicolás de Villanueva y Antón Revés conduce a la formulación de una hipótesis, apoyada en dos apéndices donde quedan examinados unos documentos mal leídos por Castro y Calvo y fuente, por ello, de varias confusiones sobre la familia de Miguel Servet. Este descubrimiento conduce a emprender de nuevo y de raíz las investigaciones sobre la familia del insigne aragonés, combinando aproximación genealógica y reconstitución prosopográfica, en busca de la verdadera identidad de Catalina Conesa, esposa de Antón Revés, y de indicios sobre el nivel de vida de la pareja. Al postular que Servet estudió en Sariñena se descarta que Juan Quintana -a quien se dedica un capítulo entero- fue su mentor y se revelan los lazos con Mosén Domingo Manobet, personaje que volvería a encontrar, años más tarde, en el estudio general de Zaragoza.

La reconstitución de la formación y de la carrera universitarias de Miguel Servet se expone a modo de crónica de la vida universitaria zaragozana de los años 1520. La datación de los títulos de bachiller y maestro en artes son ocasión de situar a Servet entre unos personajes de gran importancia en la época, como Gaspar Lax o, en menor medida, Mosén Pedro Carnicer, médico formado en Bolonia, pero condiscípulo de Servet en Zaragoza antes de viajar a Italia. Las importantes lagunas que persisten a pesar de los esfuerzos conducen a veces a la formulación de hipótesis arriesgadas, como al evocar unas posibles causas a la pendencia entre Lax y Servet. Ello se debe a la relativa novedad de la tarea emprendida y de la exploración de un periodo de gran complejidad. En las páginas consagradas a la presencia del erasmismo en Zaragoza y en su universidad, tributarias en gran parte del trabajo de Pons Fuster, se intenta aprehender el ambiente en el que pudo moverse Servet, especialmente a través de la calificación de la postura de Lax y Quintana, quien participó en la Conferencia reunida por Alonso Manrique en Valladolid en 1527, frente a la doctrina espiritual de Erasmo.

Con estas reflexiones se pone fin al «relato bastante sólido» que proyectaban componer Miguel González Ancín y Otis Towns, tal como lo afirman en las páginas de conclusión del estudio propiamente dicho. El resultado cumple perfectamente dicha ambición y ofrece un estudio comprometido en torno a los valores encarnados por la figura histórica de Miguel Servet. Pero semejante dimensión simbólica tan importante, en sí misma y para la buena conducta de la investigación, es inseparable de la restitución, según criterios científicos sólidos, de la primera parte de la existencia de Servet. Aunque sigamos reducidos a formular hipótesis en varios aspectos, es innegable que este estudio fundado sobre numerosas fuentes primarias y un examen meticuloso de la bibliografía más reciente arroja una luz nueva sobre esta parte tan mal conocida de la vida del personaje. 